Volume 4 | Issue 3

9-16-2017

\title{
The GMO/GE Debate
}

Joanna K. Sax

Follow this and additional works at: https://scholarship.law.tamu.edu/lawreview

Part of the Agricultural Education Commons, Agricultural Science Commons, Bioresource and Agricultural Engineering Commons, Biotechnology Commons, Food Biotechnology Commons, Food Processing Commons, Law Commons, Other Food Science Commons, and the Plant Biology Commons

\section{Recommended Citation}

Joanna K. Sax, The GMO/GE Debate, 4 Tex. A\&M L. Rev. 345 (2017).

Available at: https://doi.org/10.37419/LR.V4.I3.2

This Article is brought to you for free and open access by Texas A\&M Law Scholarship. It has been accepted for inclusion in Texas A\&M Law Review by an authorized editor of Texas A\&M Law Scholarship. For more information, please contact aretteen@law.tamu.edu. 


\title{
THE GMO/GE DEBATE
}

\author{
By: Joanna K. Sax, J.D. Ph.D.*
}

TABle of CONTENTS

I. Introduction.................................. 345

II. What Is GE Food?........................ 347

A. Our Entire Commercial Food Supply Is Genetically Modified ................................... 347

B. Consumer Concerns About the Safety of GE Food ....................................

III. Regulatory Framework and Legislative Issues SurRounding GE FoOd ....................... 353

A. The Coordinated Framework, Established in 1986, Governs the Regulation of GE Crops ............ 353

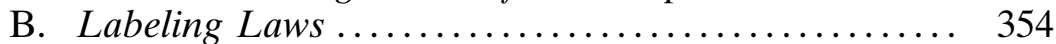

IV. Consumer Decision-Making and GE Food ........ 357

A. The Public's Concerns About GE Food May Be Explained by Perceptions of Risk ............... 357

B. Affect and Decision-Making ................. 358

V. Food-Supply Issues And GE Technology ......... 364

A. Food Supply ............................... 364

B. Environment ............................ 366

C. Herbicide-Resistant Weeds .................... 369

VI. Conclusion ................................. 370

\section{INTRODUCTION}

We live longer and healthier lives because advances in science create easier and better ways to sustain and survive. Society has an intricate relationship with biotechnology. Vaccines save lives. Fluoridated water decreases dental issues. Antibiotics treat bacterial infections. Nuclear power is a form of clean energy. With any emerging technology, the benefits do not exist in a vacuum, thus, negative consequences result as well. Our widespread uses of antibiotics are creating antibiotic-resistant strains of bacteria. Our research into nuclear energy also facilitated the creation of nuclear bombs. Perhaps it is human nature to use scientific advances for good and for bad. Acknowledging the reality that advances in science lead to both positive and negative consequences, we have to analyze the trade-offs in order to implement sound policy.

* Joanna Sax is a Professor of Law at California Western School of Law. She earned her J.D. and Ph.D. from the University of Pennsylvania. Her Ph.D. is in Cell and Molecular Biology. Portions of this Article were presented at the 2016 Texas A\&M Annual Law Review Agriculture Symposium.

DOI: https://doi.org/10.37419/LR.V4.I3.2 
Food from genetically modified organisms (GMOs) and genetically engineered (GE) food (collectively "GE") provides a prime example where advances in biotechnology are available to address a variety of issues in our food supply. GE food is in a major cross-hair in the public debate-although much of the public debate fails to fully acknowledge the contours of issues facing our food supply and the environment, and so it is in a sense a misguided public debate. Disconnect between the public debate and scientific knowledge is not new; unfortunately, many examples exist to highlight the scientific community's failure to fully educate the public. ${ }^{1}$

The GE debate appears to have an added layer of complexity: mass marketing to consumers suggesting that GE food is unsafe, harmful and bad for the planet. These marketing campaigns engage emotion, for example, that consumption of GE food will harm children. These anti-GE marketing campaigns prey on the emotions of the consumers, as many marketing campaigns do. ${ }^{2}$ This swelling of the emotional response to GE foods is very difficult to overcome.

This Article attempts to provide context and scientific support for discussing the challenges to our food supply. Addressing the issues in our food supply is critical, but the discussion has to be based on facts-and these facts must inform our regulatory policies. To do this, this Article provides an overview of the scientific literature on conventional and GE food, attempts to understand the emotional response to GE food, and provides a frame of focus for regulatory policies.

As a primer, Part II of this Article translates the science of GE technology into easy-to-understand terms. Included in this discussion is a comparison of GE food to conventional food-something that appears to be sincerely lacking in the greater public debate. This section also addresses the public's concern about safety. Critical to having an informed debate is an understanding of science.

The Article next turns, in Part III, to the legislative and regulatory issues surrounding GE food. Many types of GE products are regulated through a Coordinated Framework, established in 1986, which includes requirements for food products to be deregulated by the Food and Drug Administration ("FDA"), United States Department of Agriculture ("USDA"), and Environmental Protection Agency ("EPA"). In July 2015, the Executive Branch called for the agencies to re-visit the Coordinated Framework - and this article will discuss proposals for some much-needed change. In July 2016, Congress passed

1. See, e.g., Joanna K. Sax, The Separation of Politics and Science, 7 Stan. J.L. SCI. \& PoL'y 10 (2014); see also generally, Joanna K. Sax, Biotechnology and Consumer Decision-Making, 47 Seton Hall L. Rev. 443-63 (2017) (available at https:// papers.ssrn.com/sol3/papers.cfm?abstract_id=2910049). 1.

2. See generally, Sax, Biotechnology and Consumer Decision-Making, supra note 
and the President signed the National Bioengineered Disclosure Act, which requires the USDA to promulgate a rule regarding the labeling of genetically engineered foods. ${ }^{3}$ This Act explicitly preempts state labeling laws. In many ways, the labeling laws are a proxy for the much larger public debate about GE food. A broader discussion about labeling laws and consumer associations with them are addressed within this section.

Part IV draws on psychological research on decision-making. This Article articulates that emotion plays a role not only in marketing to consumers about food, but in actual consumer choices. For example, trends are showing that consumers want a return to the wholesomeness of food before Big Agriculture. Major players in the food industry are playing off of that to dissuade consumers from GE food choices.

We are stuck in a Rubik's Cube, of sorts, with our food supply. We have major issues to address, with nutrition, sustainability, and the environment at the forefront. ${ }^{4}$ But we are having trouble reaching these larger issues because of the misinformation guiding consumer preferences and policy decisions. In Part V, this Article discusses how biotechnology might be used to address some of the food-supply issues.

In sum, this Article utilizes scientific discovery to inform the debate over GE food. A better understanding of the technology should lead to different regulatory and legislative approaches so that the public can experience the benefits of biotechnology and the harms can be minimized.

\section{What Is GE FoOd?}

\section{A. Our Entire Commercial Food Supply Is Genetically Modified}

Perhaps the largest problem in the public debate over genetically engineered food is an unclear understanding of what it is. As a preliminary matter, multiple terms are used for different purposes, and these terms create confusion at the outset. At the most basic level, our commercially available food supply is genetically modified. We no longer eat wild-type varieties; instead we eat domesticated crops. ${ }^{5}$ Domestication alone means that the crop has been genetically modified. The term "genetically modified" or "GM" thus technically applies to all of our modern crops. Genetically modified crops created through conventional techniques will be referred to as "conventional."

3. National Bioengineered Food Disclosure Standard, Pub. L. No. 114-216, 130 Stat. 834 (2016) (amending the Agricultural Marketing Act of 1946, 7 U.S.C. $\S \S 1621-38(2012))$.

4. See, e.g., Frequently Asked Questions on Genetically Modified Foods, WorLD Health Org. (May 2016), http://www.who.int/foodsafety/publications/biotech/20 questions/en/ [https://perma.cc/L9W3-NFPM].

5. This Article focuses on plants and does not address GE animals. 
Conventional foods are created using a variety of techniques, including hybridization, chemical mutagenesis, and X-rays. ${ }^{6}$ For example, one way to create new corn seed is to treat corn seeds with radiation (which will cause mutations to the DNA), back-cross to the host corn seed, and then test the treated corn seeds for certain traits, such as resistance to a particular pest. ${ }^{7}$ This type of artificial selection has a long history, and our food supply is permeated by the creation of food through husbandry techniques. To be clear, even conventional food is genetically modified.

By way of contrast, much of the public debate and calls for mandatory labeling are about "genetically modified organisms," "GMOs," "genetically engineered," or "GE" food. These foods are genetically modified through the use of biotechnology, such as modification to the endogenous DNA. This Article will collectively refer to genetically modified crops through the use of biotechnology as genetically engineered or "GE." 8

GE crops are created in a number of ways. One way to utilize biotechnology is, for example, to introduce exogenous DNA or RNAi into the host-crop. ${ }^{9}$ That is, a particular segment of DNA or RNAi is inserted into the seed. ${ }^{10}$ The chosen DNA or RNAi sequence is known, for example, to inhibit certain processes in a pest, thereby making the crop pest resistant. Other types of biotechnology can be utilized to edit the endogenous DNA, through, for example, the use of CRISPR/Cas-9. ${ }^{11}$ CRISPR allows the editing of DNA without an exogenous vector for insertion. ${ }^{12}$ Other sophisticated techniques exist to genetically engineer food. The main difference between GE food and conventional food is the technique used to incorporate genetic modifications.

Perhaps the biggest public misperception is that GE technology creates changes to our food supply and that conventional breeding does not. To be clear, both conventional breeding and GE technology util-

6. Gregory Conko et al., A Risk-Based Approach to the Regulation of Genetically Engineered Organisms, 34 Nature Biotechnology 493, 494 (2016).

7. See generally R. Panda et al., Challenges in Testing Genetically Modified Crops for Potential Increases in Endogenous Allergen Expression for Safety, 68 Allergy 142, 142 (2013), available at http://onlinelibrary.wiley.com/doi/10.1111/all.12076/pdf [https://perma.cc/7WYL-LQBW].

8. FDA's Role in Regulating Safety of GE Foods, FDA, U.S. Dep't Health \& Hum. Servs. 1 (May 2013), https://njfb.org/wp-content/uploads/2013/07/FDA-GEAnswers.pdf [https://perma.cc/VW4V-EM6G].

9. See, e.g., Jay S. Petrick et al., Safety Assessment of Food and Feed from Biotechnology-Derived Crops Employing RNA-Mediated Gene Regulation to Achieve Desired Traits: A Scientific Review, 66 Reg. Toxicology \& Pharmacology 167, 167-68 (2013).

10. See, e.g., id.; Kai Kupferschmidt, A Lethal Dose of RNA, 341 SCIENCE 732 (2013).

11. Heidi Ledford, CRISPR, the Disruptor, 522 NAture 20, 21 (2015).

12. Id. 
ize genetic changes to obtain desired characteristics. The application of GE techniques is a more precise technique than conventional breeding. ${ }^{13}$ One advantage of this precision is that the mutations to the DNA are known. In conventional breeding, on the other hand, radiation may cause multiple DNA lesions, many of which are never characterized. ${ }^{14}$

Over many decades of research, we know much more about plant genomes. It turns out that plant genomes are quite unstable, with many molecular events occurring throughout the life cycle. ${ }^{15}$ That is, plant genomes are dynamic, with many genetic events, such as transpositions and epigenetic gene expression-and this is occurring at a rate that is much higher than previously anticipated. ${ }^{16}$ This means that changing plant genomes, either through conventional or GE techniques, is likely a very small change in what is otherwise a highly unstable genetic environment. ${ }^{17}$ And, actually, given the precise nature of recent GE technology, any disruption to a plant genome is likely to be less than conventional techniques.

That our food supply in the marketplace is genetically modified, either through conventional or GE methods, cannot be highlighted enough. This is important because we have been eating genetically modified foods for generations. And, as the safety aspect is discussed below, GE technology allows us to have a sophisticated and precise mechanism to potentially improve a food supply. The safety of GE

13. Steven H. Strauss \& Joanna K. Sax, Ending Event-Based Regulation of GMO Crops, 34 Nature Biotechnology 474, 475 (2016).

14. In reality, these additional genetic lesions probably do not need to be characterized because if they were deleterious they would be selected and eliminated. See, e.g., Nat'l Acad. Of Scis., SAfety of Genetically Engineered Foods: Approaches to Assessing Unintended Health Effects 45 (2004), available at https://www.nap.edu/read/10977/chapter/5\#45 ("However, there do not appear to be outstanding examples of mutant varieties with documented unexpected effects beyond what the mutant was selected for, despite the expectation that mutant varieties may possess and generate more unexpected outcomes than ordinary crosses because of the unpredictable and uncontrollable nature of nontargeted mutations.").

15. Strauss \& Sax, supra note 13, at 476 (citing Natalie Weber et al., Editor's Choice: Crop Genome Plasticity and Its Relevance to Food and Feed Safety of Genetically Engineered Breeding Stacks, 160 Plant Physiology 1842 (2011); Robert J. Schmitz et al., Patterns of Population Epigenomic Diversity, 495 NATure 193 (2013); Steven H. Strauss et al., Genetically Engineered Trees: Paralysis from Good Intentions, 349 SCIENCE 794 (2015)) (discussing studies that demonstrate major epigenetic and gene expression variation).

16. Strauss \& Sax, supra note 13 (citing Kent J. Bradford et al., Regulating Transgenic Crops Sensibly: Lessons from Plant Breeding, Biotechnology and Genomics, 23 Nature Biotechnology 439 (2005); Natalie Weber et al., Editor's Choice: Crop Genome Plasticity and Its Relevance to Food and Feed Safety of Genetically Engineered Breeding Stacks, 160 Plant Physiology 1842 (2011)).

17. Id. (citing Natalie Weber et al., Editor's Choice: Crop Genome Plasticity and Its Relevance to Food and Feed Safety of Genetically Engineered Breeding Stacks, 160 Plant Physiology 1842 (2011); Jamie Schnell et al., A Comparative Analysis of Insertional Effects in Genetically Engineered Plants: Considerations for Pre-Market Assessments, 24 Transgenic Res. 1 (2015)). 
techniques, just like the safety of conventional techniques, should always be evaluated. But just because the GE technology is newer, doesn't mean it is riskier.

Crops produced by conventional breeding are, in practical terms, exempt from any heavy-handed regulation prior to market entry. This could be because over many hundreds of years there has been little safety concerns with traditional husbandry techniques. It turns out that some of the traditional husbandry techniques are much more invasive to plant genomes than the precise biotechnology techniques. Thus, a concern that GE technology will somehow make food unsafe doesn't really follow our scientific knowledge. And, with CRISPR/ Cas-9, a single nucleotide change, for example, is unlikely to create any safety risk ${ }^{18}$ given the large number of genetic events regularly occurring within a plant genome. ${ }^{19}$

\section{B. Consumer Concerns About the Safety of GE Food}

A major concern expressed by consumers is whether GE food is safe. ${ }^{20}$ In this area, the public appears to trust that conventional crops are safe, but they are wary of GE crops. The scientific consensus is clear that GE crops are as safe as conventional crops. ${ }^{21}$ In many ways

18. See generally Conko et al., supra note 6, at 498.

19. See Strauss \& Sax, supra note 13, at 474-77.

20. See, e.g., Pallava Bagla \& Richard Stone, Scientists Clash Swords Over Future of GM Crops in India, 340 SCIENCE 539, 539-40 (2013); Richard Stone, Activists Go on Warpath Against Transgenic Crops-and Scientists, 331 SCIENCE 1000, 1000 (2011); John Bohannon, Zambia Rejects GM Corn on Scientists' Advice, 298 SCIENCE 1153, 1153-54 (2002); Otieno Owino, Scientists Torn Over Kenya's Recent GM Food Ban, ScIDev.Net (Nov. 30, 2012), http://www.scidev.net/global/nutrition/news/scientiststorn-over-kenya-s-recent-gm-food-ban.html [https://perma.cc/PE9L-NUAP]; Natasha Gilbert, A Hard Look at GM Crops, 497 Nature 24, 24-26 (2013); Daniel Cressy, A New Breed, 497 Nature 27, 27-29 (2013); Christopher J.M. Whitty, Africa and Asia Need a Rational Debate on GM Crops, 497 NATURe 31, 31-33 (2013).

21. See, e.g., Chelsea Snell et al., Assessment of the Health Impact of GM Plant Diets in Long-Term and Multigenerational Animal Feeding Trials: A Literature Review, 50 Food \& Chemical Toxicology 1134, 1145 (2012); Pamela Ronald, Plant Genetics, Sustainable Agriculture and Global Food Security, 188 Genetics 11, 12 (2011); Statement by the AAAS Board of Directors on Labeling of Genetically Modified Foods, Am. Ass'n for Advancement SCI. (Oct. 20, 2012), http://www.aaas.org/ sites/default/files/migrate/uploads/AAAS_GM_statement.pdf [https://perma.cc/4FH82B4F] [hereinafter Statement by AAAS]; Yan Song et al., Immunotoxicological Evaluation of Corn Genetically Modified with Bacillus thuringiensis Cry1Ah Gene by a 30Day Feeding Study in BALB/c Mice, PLOS ONE, Feb. 2014, at 1, 10; Yanfang Yuan et al., Effects of Genetically Modified T2A-1 Rice on the GI Health of Rats After 90-Day Supplement, ScI. ReP., June 2013, at 1, 6; Xueming Tang et al., A 90-Day Dietary Toxicity Study of Genetically Modified Rice T1C-1 Expressing Cry1C Protein in Sprague Dawley Rats, PLOS One, Dec. 2012, at 1, 6; see also, Philip D. Brune et al., Safety of GM Crops: Compositional Analysis, 61 J. Agric. \& Food Chemistry 8243, 8245 (2013); William D. Price \& Lynne Underhill, Application of Laws, Policies, and Guidance from the United States and Canada to the Regulation of Food and Feed Derived from Genetically Modified Crops, 61 J. Agric. Food \& ChEmistry 8349, 8353 (2013); Declan Butler, Hyped GM Maize Study Faces Growing Scrutiny, 490 NATURE 
it is a failure of the scientific community to assuage public fear and fully explain the biotechnology of how GE techniques compare to conventional husbandry techniques.

The evolution of sophisticated methods to genetically modify crops through genetic engineering is similar to other biotechnology advances. An analogy would be how we treat cancer. A hundred years ago, we actually bled people. ${ }^{22}$ Today, some chemotherapeutics make people really sick while treating cancer. This is because some chemotherapeutics target rapidly dividing cells, which are tumor cells, gut cells, and hair cells. The same drug that kills the tumor cells also kills some gut cells (causing nausea) and follicle cells (causing hair loss). ${ }^{23}$ Newer chemotherapeutics attempt to increase effectiveness and decrease the side effects. The evolution of cancer treatment is analogous to crop breeding. We have more sophisticated techniques to improve our food supply. The application of biotechnology to crops is a more sophisticated process than conventional techniques (compare bleeding patients to chemotherapeutics to gene therapy). And, in the future, we will likely have even better ways to create crops to help support sustainable farming and improve our food supply.

Public concerns about safety issues are not supported by the scientific literature. The application of bioengineering to crops has not created unintended safety consequences, which was a stated concern by the FDA in its 1992 Guidance Report. ${ }^{24}$ Rather, the use of genetically engineered crops has saved the papaya industry in Hawaii, for example. ${ }^{25}$ It can create mechanisms to improve our ability to get products to the consumers (e.g. two recently de-regulated examples: nonbrowning potatoes and apples).

The incorporation of an allergen is often cited as a safety concern. Allergenicity is in many ways more easily alleviated through GE techniques than conventional breeding. The application of GE allows the producer to know if they inserted a nut gene, for example, into a par-

158 (Oct. 10, 2012) (rejecting a paper that found adverse health events in rats fed GM corn).

22. Bloodletting, WiKIPEDIA, https://en.wikipedia.org/wiki/Bloodletting [https:// perma.cc/G8NG-VRHP].

23. Cf., Mayo Clinic Staff, Chemotherapy Nausea and Vomiting: Prevention is Best Defense, MAYo Clinic (Apr. 5, 2016), http://www.mayoclinic.org/tests-procedures/ chemotherapy/in-depth/cancer/art-20047517 [https://perma.cc/Y5C4-4FVX]; Mayo Clinic Staff, Chemotherapy and Hair Loss: What to Expect During Treatment, MAYO Clinic (Apr. 5, 2016), http://www.mayoclinic.org/tests-procedures/chemotherapy/indepth/hair-loss/art-20046920 [https://perma.cc/9DN6-Z6SG].

24. Statement of Policy: Foods Derived from New Plant Varieties, 57 Fed. Reg. 22,984 (May 29, 1992).

25. William Saletan, Unhealthy Fixation: The War Against Genetically Modified Organisms is Full of Fearmongering, Errors, and Fraud. Labeling Them Will Not Make You Safer, SLATE (July 15, 2015, 5:45 AM), http://www.slate.com/articles/health _and_science/science/2015/07/are_gmos_safe_yes_the_case_against_them_is_full_of_ fraud_lies_and_errors.html [https://perma.cc/8G67-R5KT]. 
ticular type of food. There could be reasons to insert a nut protein into a vegetable. In areas of the world that need nutritional supplements, it would be very valuable to have an endogenous crop be supplemented with a protein. But it would be known that a particular crop carries a nut protein, and safety precautions could be instituted. ${ }^{26}$ The trade-off is that a valuable protein could be delivered to malnourished people in exchange for allergenicity precautions.

The use of genetic engineering to improve pest and weed control is unlikely to make a particular food allergenic. ${ }^{27}$ The reality is that even conventional food contains a wide variety of allergen content. ${ }^{28}$ Given the uncertainties of allergens in conventional crops, there is little indication that GE crops should raise more issues about allergens than their conventional counterparts. ${ }^{29}$

The plasticity of plant genomes may be the reason that we do not see these unintended consequences of elevated expressions of endogenous toxic proteins or allergens. That plant genomes are so dynamic most likely means that a small change to the plant genome, such as a change to one or a few base pairs, will not create any additional instability. ${ }^{30}$ That is, these DNA changes are so minor in the whole scope that any chance of a negative unintended consequence is very low, and "there is no special enrichment of risk associated with any particular technology used for genetic modification, and most modified plants pose little, if any, risk regardless of the modification method used." 31

In sum, both conventional and GE food is genetically modified. Similar safety concerns face both GE and conventional breeding; this suggests that the public concerns about safety might be based on incorrect information or from anti-GE marketing campaigns. The perceptions and misperceptions can have huge consequences in the creation and implementation of regulatory and legislative policies governing GE food. ${ }^{32}$

26. It is possible that a GE technique could induce the expression of an endogenous gene known to encode an allergenic protein. The types of crops that have this potential are usually known and can be tested for expression of the allergen/protein. In any event, it cannot be known a priori whether a GE technique or a conventional technique is more likely to create this unintended consequence. See, e.g., Conko et al., supra note 6, at 498.

27. Cf. Panda et al., supra note 7, at 143 .

28. Id. at 149.

29. Id. at 150 ("These results and consideration of risks of allergy posed by nonGM food crops should raise questions about the relevance of such testing as a general safety requirement for GM plants."); NAT'L Research Council ET AL., NAT'L ACAD. OF ScIs., Safety of Genetically Engineered Foods: Approaches to Assessing Unintended Health Effects 1-4 (2004).

30. See, e.g., Conko et al., supra note 6, at 496-97.

31. Id. at 498.

32. A group is in the process of cataloging the "history" of the debate over GM crops in an effort to understand how and why this technology might succeed or fail. 


\section{Regulatory Framework and Legislative Issues SurRounding GE FoOd}

Within the past few years, and even within the past few months, a lot of activity has occurred surrounding GE food. Over the past few years, several states considered or enacted labeling laws for GE food. ${ }^{33}$ In July 2015, the Executive Branch issued a memorandum requesting that the FDA, USDA, and EPA revisit the regulatory structure governing GE crops. In July 2016, Congress passed and the President signed the National Bioengineering Disclosure Act, which requires the USDA to promulgate a rule for the labeling of GE food. This Act preempts state laws. ${ }^{34}$ This flurry of activity will be analyzed in the context of the scientific evidence.

\section{A. The Coordinated Framework, Established in 1986, Governs the Regulation of GE Crops}

In 1986, a Coordinated Framework was established to address the movement of GE crops into the marketplace. The coordinated framework incorporated the EPA, FDA, and APHIS (part of the USDA). Each agency is responsible for different pathways to entry. The EPA cares about pesticides, the FDA is concerned about food safety, and the APHIS regulates articles deemed to be plant pests. ${ }^{35}$ To bring a crop to market, it costs an estimated $\$ 136$ million and takes thirteen years. ${ }^{36}$

In 1992, the FDA issued a guidance report. At that time, the FDA stated its concerns about unknown and unintended consequences of the application of biotechnology to our food supply. ${ }^{37}$ In particular, the FDA was concerned about the expression of endogenous toxins at an unacceptable level as a result of genetic changes. ${ }^{38}$ Since the FDA issued its guidance report, scientists know much more about GE technology and plant genomes. Scientists know, for example, that plant

Vivian Moses, The Debate over GM Crops is Making History, 537 Nature 139, 139 (2016).

33. Joanna K. Sax \& Neal Doran, Food Labeling and Consumer Associations with Health, Safety and Environment, 44 J.L. Med. \& ETHICs 630, 630 (2016).

34. National Bioengineered Food Disclosure Standard, Pub. L. No. 114-216, $\S \S 293,295$, 130 Stat. 834, 835-38 (2016) (amending the Agricultural Marketing Act of 1946, 7 U.S.C. $\$ \$ 1621-38(2012))$.

35. It appears that not all types of GE crops are subject to regulation, such as, for example, crops created through gene editing. Ledford, supra note 11, at 22; see also Andrew Pollack, By 'Editing' Plant Genes, Companies Avoid Regulation, N.Y. Times (Jan. 1, 2015), https://www.nytimes.com/2015/01/02/business/energy-environment/agray-area-in-regulation-of-genetically-modified-crops.html.

36. Jose Rafael Prado et al., Genetically Engineered Crops: From Idea to Product, 65 Ann. Rev. Plant Biology 769, 770 (2014); see also Pollack, supra note 35.

37. Statement of Policy: Foods Derived from New Plant Varieties, 57 Fed. Reg. 22,984, 22,985-87 (May 29, 1992).

38. Id. at $22,986-87$. 
genomes are very dynamic, with ever-changing gene expression. ${ }^{39}$ Scientists know from many studies that the insertion of a particular piece of DNA or gene editing is unlikely to create any additional dynamic response compared to the normal profile. ${ }^{40}$ All together this means that changes to plant DNA through biotechnology are likely to have little to no impact on the expression of endogenous allergens or toxins as compared to conventional breeding. ${ }^{41}$

Given the many decades of research in GE crops, in July 2015, the White House issued a Memorandum requesting that the regulatory agencies revisit the Coordinated Framework with the goal of balancing safety, environment, welfare, and innovation. ${ }^{42}$ This Memorandum was possibly a welcomed call by many deeply embedded in this field who have been calling for science-based policy change for many years. ${ }^{43}$ While we do not know how the Coordinated Framework will be changed, many are proposing some overarching principles to guide policymakers. $^{44}$

\section{B. Labeling Laws}

Over the past few years, numerous states have considered and/or passed mandatory labeling laws for foods derived from or containing GE crops. Proponents of these laws argue that they support consumer rights, but labeling-law lobbyists appear to be wrapped up in marketing campaigns, suggesting that labeling is needed because consumers should be wary.

It seems innocent enough - why not provide the information to the consumer and then let the market decide? The issue turns into asking what information is needed to allow consumers to make informed decisions.

A canvass of literature and reports on consumer decision-making, as relevant to food, provides a lot of context for these labeling laws. Some hypothesize that other financial interests are pushing the labeling debate. The organics industry, for example, may prefer to have GE labels, allowing them to market that organic food is healthier compared to GE, or to indicate that organics use less pesticide than

39. Strauss \& Sax, supra note 13 , at $475-76$.

40. Id. at 476.

41. See Conko et al., supra note 6, at 498.

42. Memorandum from John P. Holdren, Assistant to the President for Science and Technology, et al. to Food and Drug Admin., Envtl. Protection Agency, \& Dep't of Agric. (July 2, 2015), available at https://www.epa.gov/sites/production/files/201612/documents/modernizing_the_reg_system_for_biotech_products_memo_final.pdf [https://perma.cc/TEB2-V9CE].

43. See, e.g., L. Val Giddings \& Bruce M. Chassy, Igniting Agricultural Innovation: Biotechnology Policy Prescriptions for a New Administration, ScI. Progress (June 2009), https://www.scienceprogress.org/wp-content/uploads/2009/06/giddings_chassyag_biotech.pdf [https://perma.cc/JV3J-Q59T]; see also Conko et al., supra note 6, at 494.

44. See, e.g., Strauss \& Sax, supra note 13, at 476. 
GE. But it is unclear if consumers know that organic foods are created through conventional breeding or that pest-resistant GE crops also use less pesticide. Put differently, some suggest the labeling debate is a financially motivated push by folks that support organic food. ${ }^{45}$

In addition, some anti-GE food activists are paid enormous sums of money to promote misperceptions about the safety of GE food. ${ }^{46}$ That is, the financially interested players stand to lose a lot of money if the public really understands GE food technology. Thus, they institute tactics intended to scare the consumer, such as mandatory labeling.

Substantively, the labeling debate suffers from the same shortcomings as the public debate about safety. As discussed above, the scientific consensus is that GE food is as safe as conventional food. Even assuming, arguendo, that GE food could have an elevated expression of an endogenous protein, some products derived from GE foods, such as vegetable oil, do not contain DNA from the original crop. This is because oil is made by extracting the triglycerides from plants, which are then refined and possibly processed. ${ }^{47}$ This is the same for sugar. That is, it contains no DNA or protein from the original plant. ${ }^{48}$ So even though safety is not an issue, it should not matter for the additional reason that raw food ingredients such as sugar and oil do not contain any DNA or protein.

Others have expressed concerns that the labeling requirements could give effect to non-fact based beliefs that GE foods are not safe for consumption. ${ }^{49}$ The American Medical Association and the American Association for the Advancement of Science both announced that there is no health or safety reason to label food as GE or not. ${ }^{50}$

It appears that it is the anti-GE factions that want mandatory labeling, while those who understand the science see no need for labeling. ${ }^{51}$ That, in and of itself, should provide context for the push for labeling.

45. Cf., Saletan, supra note 25.

46. See, e.g., Michelle Miller, Who Funds the Grassroots Anti-GMO Movement?, Genetic Literacy Project (Sept. 15, 2016), https://www.geneticliteracyproject.org/ 2016/09/15/funds-grassroots-anti-gmo-movement/ [https://perma.cc/65QZ-Q4GF]; Jon Entine, Hawai'i Anti-GMO Activists Rely on Mainland Millionaires for 'Grassroots' Campaign, Forbes (Oct. 2, 2013, 10:49 AM), http://www.forbes.com/sites/jonentine/ 2013/10/02/hawaii-anti-gmo-activists-rely-on-mainland-millionaires-for-grassrootscampaign/\#7a9acc01482c [https://perma.cc/7ZT6-U662].

47. A.S. Bawa \& K.R. Anilakumar, Genetically Modified Foods: Safety, Risks and Public Concerns-A Review, 50 J. FoOd SCI. \& TeCH. 1035, 1036 (2013).

48. Id.

49. James E. McWilliams, The Price of Your Right to Know, Slate (May 20, 2014, 7:17 AM), http://www.slate.com/articles/health_and_science/science/2014/05/gmo_ food_labels_would_label_laws_in_vermont_maine_connecticut_increase_food.html [https://perma.cc/YB2M-3DWV].

50. American Medical Association: GMO Labeling Not Necessary, Huffington Post (June 21, 2012, 4:54 PM), http://www.huffingtonpost.com/2012/06/21/gmo-labeling-ama-american-medical-association_n_1616716.html [https://perma.cc/8AJVZ688]; Statement by AAAS, supra note 21 .

51. Cf. German Scientists Push for GM, 348 SCIENCE 842, 842 (2015). 
To counteract this, supporters of GE food are considering embracing GE labeling as a way to suggest that GE food should be favored. An analogy to this tactic is how President Obama embraced the term "Obamacare." In Germany, for example, scientists who support GE crops are pushing for GE labeling in the hopes that a labeling law will demonstrate to the public how pervasive GE food is in the marketplace so that consumers can understand that they have been eating GE food all along - with no adverse health consequences. ${ }^{52}$

Consumers should weigh the cost of labeling against the information it provides. Right now, components of GE and conventional crops are co-mingled in factories, and it could be expensive to create separate facilities to segregate the crops. ${ }^{53}$ That is, it is not just the cost of adding an extra few words to a label, as some might suspect. ${ }^{54}$

While a mandatory labeling law is neutral in the sense that it doesn't require manufacturers to say anything negative or positive about GE food, the labeling in and of itself signals that there must be a reason for the label. Consumers could wonder-why does this need to be labeled? Is it because I need to be warned about something? In its application, mandatory labeling may take advantage of consumers' perceptions that there might be some risk associated with the food.

To understand more about consumer reactions to labeling, one study conducted a survey asking subjects how labels impacted their perceptions of health, safety, and the environment. ${ }^{55}$ The labels tested included "organic," "natural," "low fat" or "fat free," "GMO," or "non-GMO." 56 Within these labels, the study tested three different food products: cereal, apples, and sugar. ${ }^{57}$ Sugar was tested because it is a raw ingredient with no protein. Thus even if someone opposed GE food for perceived safety reasons, it would not make sense for sugar. Apples were tested because of some evidence that organic food has a lower safety profile compared to conventional produce. ${ }^{58}$ Cereal is a generic food used to obtain a general sense of perceptions. Also, the label "GMO" was used instead of GE because GMO is the term generally used with the public.

The results of the survey demonstrated that subjects associate greater health, safety, and environmental friendliness with all labels

52. Id.

53. McWilliams, supra note 49.

54. Id.

55. Sax \& Doran, supra note 33 , at $630-37$.

56. $I d$.

57. Id.

58. See Robert Wager et al., Organics Versus GMO: Why the Debate?, GenETIC Literacy Project (Oct. 15, 2013), http://www.geneticliteracyproject.org/2013/10/15/ organics-versus-gmo-why-the-debate/ [https://perma.cc/675W-JCTX]; Avic Mukherjee et al., Preharvest Evaluation of Coliforms, Escherichia coli, Salmonella, and Escherichia coli O157:H7 in Organic and Conventional Produce Grown by Minnesota Farmers, 67 J. Food Protection 894, 900 (2004). 
compared to the GMO label, regardless of the food product tested. ${ }^{59}$ In other words, the label really mattered to the subjects. The subjects' associations with health, safety, and environmental friendliness are not an analysis shared by the experts. While it seems perfectly reasonable to label food so that consumers can make informed decisions, it appears that labeling a food product as GMO or not does not do so. Put differently, consumers are inappropriately assigning risk based on the food label.

After several states considered or enacted labeling laws, in 2016, Congress passed and the President signed the Bioengineered Food Disclosure Act.$^{60}$ This Act preempts state law. ${ }^{61}$ Pursuant to the Act, the Secretary of the USDA must promulgate a national labeling law within the next two years. ${ }^{62}$

Labeling laws are really a red herring for a larger issue, that is, understanding why consumers believe that products labeled "GMO" are less healthy, safe, and environmentally friendly. Studies aimed at understanding consumer decision-making will likely provide great social value. $^{63}$

\section{Consumer Decision-Making and GE Food}

Given the larger issue demonstrated through labeling laws, perhaps it is important to step back and consider how consumers make decisions. Recent scholarship analyzing emotion and perceptions of risk in decision-making may assist in explaining public resistance to this issue. ${ }^{64}$

\section{A. The Public's Concerns About GE Food May Be Explained by Perceptions of Risk}

Current understanding of the molecular nature of plant genomes is likely beyond the typical information both possessed and processed by most consumers. Instead, through a series of marketing campaigns and inept regulatory policies, some consumers inappropriately assign risk to GE food, or, frankly, even may not understand that conventional food is also genetically modified.

Risk is an important component in the debate surrounding GE food. We know that people are more likely to accept the known with

59. Sax \& Doran, supra note 33, at 634-35.

60. National Bioengineered Food Disclosure Standard, Pub. L. No. 114-216, 130 Stat. 834 (2016) (to be codified at 7 U.S.C. $\$ \S 1639-39 j$ ).

61. Id.

62. See, e.g., id.

63. Sax, Biotechnology and Consumer Decision-Making, supra note 1.

64. The Author is grateful to a colleague for the introduction of Slovic's research on affect to address this debate as well as others. Aspects of Part IV are more broadly discussed and evaluated in Sax, Biotechnology and Consumer Decision-Making, supra note 1. 
greater risk than an unknown with smaller risk. ${ }^{65}$ Toxicologists, for example, deal with these risk assessments when studying the use of pesticides and herbicides. ${ }^{66}$ Low levels of exposure to pesticides and herbicides, for example, have functionally no difference in a risk profile compared to no exposure.$^{67} \mathrm{But}$ pesticides and herbicides are marketed to consumers as toxic, regardless of exposure level. Consumers experience this especially in organic food marketing. However, the safety risk assessment of pesticide exposure between consuming conventional food and organic food is not different. ${ }^{68}$

Risk perception may help explain consumer resistance to GE food. The application of biotechnology to our food supply is less well known; thus, consumers may perceive it as riskier. On the other hand, consumers have been eating conventional foods for many years and believe that they are safe. That is, consumers say, "I don't want to take the risk." But, over dozens of years and studies, the risk of eating conventional food and GE food is the same-both are safe. ${ }^{69}$

Current public-safety debate centers on GE foods. But it doesn't really make sense, scientifically, to target GE and not conventional food..$^{70}$ Actually, a case could be made that GE food is safer because it is precise; whereas with conventional techniques, a dose of radiation may mutate multiple portions of a seed's DNA, but these other changes remain unknown. Arguably, GE techniques may be preferable.

Scholarship in the area of risk perception helps elucidate a reason why consumers might perceive GE food as risky. Perception of risk is easily extorted by competitors in the marketplace, impacting consumer decision-making.

\section{B. Affect and Decision-Making}

GE food is part of a long laundry list of examples in which the public, or public perception, is not fully informed by the science. Any number of controversial issues can be added to this list, such as vac-

65. Cf., Paul Slovic et al., The Affect Heuristic, 177 Eur. J. Operational Res. 1333 passim (2007).

66. See, e.g., Dave Stone, Cannabis, Pesticides and Conflicting Law: The Dilemma for Legalized States and Implications for Public Health, 69 Reg. Toxicology \& Pharmacology 284, 286 (2014) ("A risk assessment is conducted using a variety of scenarios and exposure factors to determine how much, where and under what circumstances a pesticide product can be registered.").

67. Saletan, supra note 25.

68. $C f$., id.

69. $I d$.

70. See Brian Heap, Europe Should Rethink its Stance on GM Crops, 498 Nature 409 (2013) ("Indeed, the changes induced by modern genetic modification often cannot be distinguished from those produced by conventional breeding or natural genetic variation."). 
cinations and fluoridated water. ${ }^{71}$ Whether it is a mistrust of science, a conflict with personal values, political jockeying, or simply believing misinformation, this struggle between science and society is a constantly revolving loop. ${ }^{72}$ Deniers of human contribution to climate change or evolution, to highlight a few examples, can find information to support their beliefs through Internet searches. ${ }^{73}$ This entrenches people in these positions because they can find some information that supports their beliefs, regardless of the quality of the information.

The role of "affect" in decision-making is increasingly recognized in decision-making literature. ${ }^{74}$ Paul Slovic and colleagues articulately explain the role of affect, meaning the faint whisper of emotion, or the "goodness" or "badness," experienced as part of decision-making. ${ }^{75}$ That is, humans pick-out new clothes because they think they will look good in them, or we make decisions that replicate a feeling of goodness. Interestingly, affect differentiates the mental state of people. For example, a study by Antonio Damasio demonstrated that patients with a particular type of brain injury that impairs their ability to feel (although leaves intact intelligence and capacity for thought) make decisions akin to sociopaths, with little regard for the goodness or badness of their decisions. ${ }^{76}$

Studies show that positive and negative stimuli can influence decision-making. ${ }^{77}$ Building on that, empirical studies demonstrate the close relationship between imagery, affect, and decision making. ${ }^{78}$ Perhaps, by lay example, affect helps explain the effectiveness of the tobacco industry in obtaining smokers. Positive words, such as "cool" or "relaxing" might influence the decision to smoke. Old movies in which the stars are seen smoking might also impact decisions. On the other hand, commercials showing the disease and even death associated with smoking might be used to influence people not to smoke. That is, the impression of what it means to smoke might impact the decision.

The relationship between decision-making and probability might also be understood using the affect framework. If, for example, there is a $95 \%$ probability that a particular policy decision can save 100 lives, people might be more likely to support that decision than a policy claiming that it will save 95 lives (without reference to the

71. Joanna K. Sax, Separating Fact from Fiction, Petrie-Flom Ctr., Harvard L. Sch.: Bill Health (Aug. 27, 2014), http://blogs.law.harvard.edu/billofhealth/2014/08/ 27/separating-fact-from-fiction/ [https://perma.cc/5ELP-S33G].

72. See, e.g., Sax, The Separation of Politics and Science, supra note 1, at 11.

73. See, e.g., George Johnson, The Widening World of Hand-Picked Truths, N.Y. Times Aug 24, 2015, at D6.

74. Slovic et al., supra note 65, at 1334.

75. Id. at 1333.

76. Id. at $1334-35$.

77. Id. at 1336 .

78. Id. at 1338. 
probability).$^{79}$ But probability does not explain the entire decision making process because if the affect is negative, say, for example, the dread associated with a nuclear energy power plant leak, then even if the probability is low that anything will go wrong and the probability is high that cleaner energy will be produced, the negative feelingthat is, the affect-impacts how people make decisions. ${ }^{80}$

The implications of affect in decision making also help us understand decision-making associated with risk - that is, the perception of risk. ${ }^{81}$ According to studies by Paul Slovic and others, the role of affect explains perceptions of risk and benefits. ${ }^{82}$ In these studies, subjects were provided information about risk and benefits: If the information provided stated that the risk was low for a particular technology, subjects perceived an increase in benefit. ${ }^{83}$ When researchers varied the information provided, the perceptions followed a pattern. For example, if the information stated that the benefit would be high, the perception was that the risk was low; conversely, if the information said the benefit was low, the risk perception was high. ${ }^{84}$

If affect offers an alternative theory to cognition in decision-making, then how could it be used to make inconsistent or irrational decisions ${ }^{85}$ The role of affect in decision-making can be used to influence consumers- "If you buy this outfit, you will look thin and happy just like this model." 86 "If you eat this organic product, you will feel great because it is "natural." "87

The influence of affect has arguably impacted the debate over GE foods. The term "Frankenfood" to describe GE products elicits a negative feeling, for example. ${ }^{88}$

The organic industry has persuasively marketed organic products as safe, natural, healthy, and good for you. This industry, which topped over $\$ 39$ billion in sales in $2014,{ }^{89}$ appears to utilize affect to influence consumers. According to the Organic Trade Association, "[w]ith more and more U.S. families choosing organic products when they shop, OTA's survey uncovers that health motivation is still a top reason to

79. See id. at 1341.

80. Id. at 1342 .

81. Id. at 1343.

82. Id.

83. Id. at $1343-44$.

84. Id. at 1343 fig.3.

85. See id. at 1347.

86. Id.

87. See, e.g., id.

88. Id. at 1348 .

89. U.S. Consumers Across the Country Devour Record Amount of Organic in 2014, ORganic Trade Ass'N, https://www.ota.com/news/press-releases/18061 [https:/ /perma.cc/LR7A-LXC3]. 
go organic, parents want to steer clear of GMOs, and that children are influencing purchasing decisions more than ever before." 90

Consumers associate the term "organic" with chemical-free, natural, and cage-free, even though many consumers have little knowledge of standard farming practices. ${ }^{91}$ It seems that consumers often turn to buying organic food when they have their first child-perhaps wanting to give their babies seemingly healthier food..$^{92}$ Health is considered a main reason why consumers purchase organic, although not far behind are environmental concerns, taste, and safety. ${ }^{93}$ The health factor appears to be guided by a belief that the use of pesticides associated with conventional farming is unsafe and that organic food, itself, is healthier. ${ }^{94}$ Of importance, risk-assessment measures have been conducted regarding pesticides, ${ }^{95}$ and no studies demonstrate any difference in nutrition in organic versus conventional food. ${ }^{96}$

Environmental concerns, also topping the list of reasons why consumers purchase organics, appear to be based on the perception that pesticides are harmful to the environment. ${ }^{97}$ While this may be true, to some extent, other farming practices also have environmental impacts, to which the organic food industry is not immune. ${ }^{98}$ One study asked subjects about their associations with organic, conventional, and GMO farmers. ${ }^{99}$ In this study, subjects rated more positive motivations with organic farmers than with GMO farmers. ${ }^{100}$

Friendlier treatment of animals is also a consumer-stated preference. ${ }^{101}$ The term "cage-free," for example, likely provokes feelings that chickens were freely wandering in a lush field. The reality is that "cage free" means the "chickens were uncaged and able to freely roam a barn or other facility, but they generally don't have access to the outdoors[,]" but in practical terms they are enticed, by their food

90. Consumer Attitudes and Beliefs Study, Organic Trade Ass'n, https://theorganicreport.com/resources/consumer-attitudes-and-beliefs-study [https://perma.cc/6JT J-KDJF].

91. Renée Shaw Hughner, Pierre McDonagh, Andrea Prothero, Clifford J. Shultz II \& Julie Stanton, Who Are Organic Food Consumers? A Compilation and Review of Why People Purchase Organic Food, 6 J. Consumer Behav. 94, 96 (2007).

92. Id.

93. Id. at 101.

94. Id.

95. Overview of Risk Assessment in the Pesticide Program, EPA, https://www.epa .gov/pesticide-science-and-assessing-pesticide-risks/overview-risk-assessment-pesti cide-program [https://perma.cc/738X-WSC7].

96. Hughner et al., supra note 91, at 101.

97. Id. at 102 .

98. See Saletan, supra note 25.

99. Sax \& Doran, supra note 33, at 630-32.

100. Id. at 633 .

101. Hughner et al., supra note 91, at 102. 
supply, to stay huddled with the other chickens. ${ }^{102}$ And, to be clear, "cage free" chickens do not necessarily have access to the outdoors.

Many of the preferences stated by consumers of organic food can be accomplished through GE technology. Pest-resistant GE food, for example, means that less pesticide is needed to grow the food product. If health is a major concern, GE food can provide a mechanism to supplement food with important nutrients. ${ }^{103}$ Perhaps it might even be fair to say that some organic farmers might want to embrace GE technology, but their industry prohibits it. ${ }^{104}$

Consumers may not fully understand that some evidence suggests that organic foods have a worse safety record than some non-organic foods. ${ }^{105}$ Organic farmers use manure, plentiful with bacteria, as a natural fertilizer. ${ }^{106}$ Applied improperly, this can lead to contamination and major health and safety problems. ${ }^{107}$ Organic food, unlike GE food, is, in practice, unregulated prior to entering the marketplace. ${ }^{108}$

Consumers receive a lot of information through the Internet, especially through activists. Terms may be used that are meant to scare consumers away from GE food, claiming that GE food can harm children, for example. ${ }^{109}$ And activists prey on the corporate behavior of well-known agriculture companies to influence consumer decisions.

A well-known anti-GMO activist Mark Lynas acknowledged that the reason why big agriculture companies, such as Monsanto, dominate the GE world is because anti-GMO activists, including Lynas himself, have made it next to impossible for small companies and niche products to enter the marketplace. ${ }^{110}$ In an amazing turn of events, Lynas recently announced that he was wrong. ${ }^{111}$ Moved by the scientific consensus, Lynas acknowledged that over the past 20 years, he could no longer support his anti-GMO view. ${ }^{112}$

Another well-known anti-GMO activist is Vandava Shiva. Michael Spector's New Yorker article chronicling Shiva suggests that Shiva's N.G.O., Nadanya, provides strong financial support for the anti-GMO

102. David Kesmodel, Free-Range? Cage-Free? Organic? A Consumer's Guide to Egg Terminology, The Wall Street J. (Mar. 11, 2015, 3:00 PM), http://www.wsj .com/articles/free-range-cage-free-a-consumers-guide-to-egg-terminology-1426100409.

103. See, e.g., Wager et al., supra note 58.

104. $I d$.

105. See id.; Mukherjee et al., supra note 58, at 900.

106. Wager et al., supra note 58.

107. Id.

108. Id.

109. $C f$., Saletan, supra note 25.

110. Torie Bosch, Leading Environmental Activist's Blunt Confession: I Was Completely Wrong to Oppose GMOs, SLATE (Jan. 3, 2013, 2:27PM), http://www.slate.com/ blogs/future_tense/2013/01/03/mark_lynas_environmentalist_who_opposed_gmos_ad mits_he_was_wrong.html [https://perma.cc/FQG6-8QX6].

111. Id.

112. $I d$. 
movement in India. ${ }^{113}$ Shiva's fame can be linked, at least in part, to her robust anti-GMO views.

Vani Hari, otherwise known as the Food Babe, is a well-known antiGMO activist. ${ }^{114}$ Blog posts on the Food Babe website promote an anti-GMO sentiment, including, for example, a recent post touting the work of the Hawaii chapter of the Center for Food Safety: "They fight back against the corrupt food system with petitions and have bravely taken legal action to force our government to create stronger regulations in regards to GMOs and chemicals that are harming our bodies, the environment, and farm animals." 115 If health, safety, environmental, and other differences actually exist they should be discussed. But the implications that eating GE food is unhealthy or that GE foods might harm humans and animals may stem from other financial incentives, given that these implications cannot be supported by science.

Consumer preferences for organic, non-GE, or GE food are certainly reasons to have different products in the marketplace. But a simple Google search for comparing organics and GE food shows a wide selection of websites dedicated to saying that organics are natural, healthier, and safer and GE food is dangerous, less healthy and bad for the environment. This connection to goodness or badness, otherwise known as affect, influences consumer preferences-even though the science does not support the difference.

The "affect heuristic," a term coined by Paul Slovic, might also explain the risk/benefit disconnect facing GE food. If, for example, a consumer perceives the risk of GE food as very high, he or she will perceive the benefit as very low. This perception is a huge barrier to overcome. How can the science be communicated to the consumer that GE food is as safe as conventional food on the market? Consumers perceive conventional food as safe and correspondingly perceive that the benefit is high. How can this rationale be applied to GE food?

The future of our food supply is a major issue. Consumers must be fully informed to obtain policies that are based on the science and not policies based on who can win marketing campaigns and manipulate consumers the most.

113. Michael Specter, Seeds of Doubt, The New Yorker (Aug. 25, 2014), http:// www.newyorker.com/magazine/2014/08/25/seeds-of-doubt [https://perma.cc/8R2HHKW6].

114. Vani Hari, About Vani Hari, Food BABE, http://foodbabe.com/about-me/ [https://perma.cc/WL8T-AMJS].

115. Vani Hari, The Unethical Tactics of the Chemical Industry to Silence the Truth, FoOD BABE (Oct. 6, 2016), http://foodbabe.com/2016/10/06/the-unethical-tactics-ofthe-chemical-industry-to-silence-the-truth/\#more-26072 [https://perma.cc/2EX86DAD]. 


\section{Food-Supply Issues And GE Technology}

Our planet faces major issues with our ongoing food supply. Malnutrition is the number one health problem facing humanity. Agriculture is inherently unfriendly to the environment. We face global climate change, water resource problems, and biodiversity issues. GE crops are not the solution to all of these issues (and in some cases they may magnify the issues), but a robust discussion of ways that biotechnology might assist in addressing our food-supply issues is warranted.

\section{A. Food Supply}

Possible benefits of GE foods include the creation of food that can withstand drought conditions, delayed ripening so that food has a greater chance of reaching the market, increased nutritional content, and faster growing crops. ${ }^{116}$

A recent study published by the Union of Concerned Scientists stated that crop yield of GE foods is no greater than the yield of other crops. ${ }^{117}$ At first glance, this appears to mean that there is no point to GE foods because the crops do not yield more food than other crops. But this cannot be the full story. First, the report concluded that overall yield was not greater for GE crops compared to non-GE crops, even though the report included individual studies where GE-crop yield was higher compared to non-GE crops. ${ }^{118}$ Second, while yield is important, the ability to get food to market is also important. We need to know whether more GE foods made it to the marketplace compared to other crops. With crops subject to loss due to over-ripening, it may be that a GE crop may have a better chance of making it to market. Finally, GE crops have not been designed to increase yield, so a yield analysis does not really tell us anything. ${ }^{119}$

In the US, two interesting GE food products recently received deregulated status: the Arctic Apple and the Innate Potato. The Arctic Apple does not brown when sliced. ${ }^{120}$ That is, the Arctic Apple is genetically engineered so that the genes that trigger the browning pro-

116. See, e.g., Ronald, supra note 21, at 12; N. V. Fedoroff et al., Radically Rethinking Agriculture for the 21st Century, 327 SCIENCE 833, 833 (2010); Michael Eisenstein, Discovery in a Dry Spell, 501 Nature S7, S7-S8 (Supp. 2013); see also, Monsanto, Water Conservation Key to Monsanto's Ongoing Commitment to Sustainable Agriculture, 501 Nature (SPOnsor Feature 2013) (noting that this looks like an advertisement).

117. Doug Gurian-Sherman, Failure to Yield: Evaluating the Performance of Genetically Engineered Crops 1 (2009), available at http://www.ucsusa .org/sites/default/files/legacy/assets/documents/food_and_agriculture/failure-to-yield .pdf [https://perma.cc/WQ58-P43E].

118. Id. at 33.

119. Nina V. Fedoroff, Hakim's Effort to Skewer Biotech Crops in Sunday's NY Times, OFW LAw (Nov. 1, 2016), http://www.ofwlaw.com/2016/11/01/hakims-effortto-skewer-biotech-crops-in-sundays-ny-times/ [https://perma.cc/PR4S-3GS9].

120. Introducing Nonbrowning Apples, ARCTIC ApPLes, http://www.arcticapples .com/arctic-apples-r/introducing-nonbrowning/ [https://perma.cc/Y7JC-D4Z4]. 
cess are shut down. This process does not change the nutritional content or create any safety issues - it is simply a way to have a nicer sliced apple. ${ }^{121}$ These apples could, for example, easily be included in school lunches as a healthy snack. Currently, sliced apples in the grocery store contain preservatives to maintain their color, but the Arctic Apple solves that problem so that no preservatives are needed. ${ }^{122}$

The Innate Potato is similar to the Arctic Apple in that it is less susceptible to black spot from bruising "caused by impact and pressure during harvest and storage than conventional potatoes and have lower levels of asparagine" and sugars. ${ }^{123}$ This allows more potatoes to survive harvesting and shipping to make it to market. ${ }^{124}$ This means that farmers can grow fewer potatoes but still get the same amount to market, meaning less water, fertilizer, and pesticides for growing essentially the same final yield. ${ }^{125}$

Another thing that many consumers do not realize is that the high cost and regulatory burden of bringing a GE food product to market actually creates perverse incentives. ${ }^{126}$ That is, because of the enormous costs associated with manufacturing GE food, only large-scale crops with generalizable appeal hit the marketplace, such as pest-resistant soybeans. ${ }^{127}$ This means that many niche products that might grow well in a sub-climate never come to fruition. For example, a particular pest might be a problem in one climate area versus another, but public-sector farmers and the biotechnology industry are essentially disincentivized from producing a pest-resistant product because they cannot afford to. ${ }^{128}$ The public is missing out on many of the local and niche benefits that GE technology can provide.

Another benefit could be that certain GE crops may grow faster or in off-seasons or contain higher levels of important nutrients. ${ }^{129}$ It may be possible to address hunger issues by creating crops that are more likely to reach desperate populations. Golden rice, a rice that is genetically engineered to produce a precursor to Vitamin A, has been held up in a regulatory abyss. ${ }^{130}$ Many Africans are deficient in Vita-

121. See generally id.

122. See Frequently Asked Questions:Why Arctic Apples Are Safe (and Delicious!), ARCTIC APPLES, http://www.arcticapples.com/arctic-apples-r/faq/ [https://perma.cc/ NEF8-R8VJ].

123. Press Release, Innate by Simplot, USDA Deregulates Innate ${ }^{\mathrm{TM}}$ Potatoes (Nov. 7, 2014), available at http://www.innatepotatoes.com/newsroom/view-news/usda-deregulates-innate-potatoes [https://perma.cc/HR23-BDYG].

124. The Science, InNATE By Simplot, http://www.innatepotatoes.com/get-answers [https://perma.cc/9VBZ-7MJV].

125. Id.

126. Strauss \& Sax, supra note 13 , at 475.

127. See id. at 476.

128. See id. at 475.

129. Bawa \& Anilakumar, supra note 47, at 1038.

130. See Saletan, supra note 25. 
min A. ${ }^{131}$ Golden rice is not yet available to feed ailing populations. Food supply should be a focused area of research studies.

\section{B. Environment}

Another possible benefit is that pest-resistant GE crops may be better for the environment because farmers can use fewer chemicals when caring for the crop. ${ }^{132}$ Or it may be that traditional weed-killing chemicals or insecticides are no longer effective, and GE technology can address this problem. ${ }^{133}$ In addition, it may be better for farmers and their employees to avoid occupational exposure to insecticides and weed killers. ${ }^{134}$

These benefits, if they are indeed proven to be benefits, need to be considered in light of potential environmental harms. Farming, in general, is not environmentally friendly. But steps can be taken to reduce negative environmental impact.

A recent article by John A. Pickett and colleagues addressed an idea that GE crops may be used to enhance sustainable farming. ${ }^{135}$ To address pest management, a "push-pull" system of farming can be implemented to naturally exploit biosynthetic pathways of crops that have endogenous mechanisms to control pests. ${ }^{136}$ In essence, plants that naturally attract beneficial pests, which are predators of the maincrop pest, can be planted around or among the selected crop type. ${ }^{137}$ This allows for an exploitation of beneficial organisms to serve as the pesticide. ${ }^{138}$ At the same time, these authors suggest that GE crops, with pest-resistance genes or RNAi, can be used to attract and kill the pests. ${ }^{139}$ The combination of these effects, both the attraction of beneficial pests ("pull" crops) along with pest-resistant GE crops ("push" crops), could be engineered to create a robust effect. ${ }^{140}$ In addition to

131. Micronutrient Deficiencies: Vitamin A Deficiency, World Health Org., http://www.who.int/nutrition/topics/vad/en/ [https://perma.cc/K4NX-H7NB], (last visited March 27, 2017) ("Vitamin A deficiency is a public health problem in more than half of all countries, especially in Africa and South-East Asia, hitting hardest young children and pregnant women in low-income countries.").

132. Ronald, supra note 21 , at 16 ; Fedoroff et al., supra note 116, at 833; R. P. Freckleton et al., Deciding the Future of GM Crops in Europe, 302 SCIENCE 994, 995 (2003); cf. Qiang Wang, China's Scientists Must Engage the Public on GM, 519 NATURE 7,7 (2015).

133. Robert F. Service, What Happens When Weed Killers Stop Killing?, 341 ScIENCE 1329, 1329 (2013); Amy Maxmen, Under Attack, 501 Nature S15, S15-17 (Supp. 2013).

134. Henry Miller, Editorial: In Defence of Science-Based Regulation, 13 J. OF Com. BioTECHNOLOGY 65, 65 (2007).

135. John A. Pickett et al., Push-pull Farming Systems, 26 Current Op. BiotechNOLOGY 125, 125 (2014).

136. Id.

137. $I d$.

138. Id.

139. Id. at 126.

140. Id. 
pest resistance, some "pull" crops are valuable for feeding farm animals and adding nitrogen to the soil, thus improving soil health and reducing the amount of fertilizer needed. ${ }^{141} \mathrm{GE}$ technology could also be used to enhance the pull crops, thus increasing the attraction of beneficial pests. ${ }^{142}$ This is not as easy as it sounds. The process of attracting beneficial pests through pulsation release of hormone equivalents is not easy to accomplish or mimic. ${ }^{143}$ These genetic modifications will still impact the natural balance of beneficial predators and pests, and these changes will need to be monitored to determine environmental impact. But this area offers insight into ways that molecular biology can be incorporated into a sustainable farming model.

Other options exist to combat agricultural harms to the environment. These include requiring areas of land dedicated to wildlife, allowing a minimal set of weeds to grow, rotating crops, improving fertilizers, and increasing other sustainable farming techniques. ${ }^{144}$ To protect beneficial insects, birds, or other wildlife, the U.S. government provides incentives for farmers to set aside land specifically for wildlife. ${ }^{145}$ In Europe, farmers may be restricted from using some forms of weed-control measures so that some weeds are allowed to grow. ${ }^{146}$

Farmers who use GE crops demonstrate a lower use of pesticides and less-toxic herbicides. ${ }^{147}$ The lower use of toxic herbicides and pesticides is correlated with a decreased use of fuel (and related carbon dioxide release) due to decreased use of farming equipment to spray the fields. ${ }^{148}$ It is unclear whether the lower use of toxic herbicides, pesticides, and fuel creates an actual environmental advantage. If, for example, farmers do not rotate crops, increase fertilizer, or fail to employ sustainable farming techniques because they have GE seeds or crops, then the lower use of toxic herbicides, pesticides, and fuel may not be a net gain. Data is needed to address the potential trade-offs.

In the spring of 2015, Brazil approved the planting of GE eucalyptus trees that are modified to grow about $20 \%$ more wood compared to standard eucalyptus trees. ${ }^{149}$ FuturaGene, the company that de-

141. Id. at $126-27$.

142. Id. at 129 .

143. See id.

144. See, e.g., Paul C. West et. al, Leverage Points for Improving Global Food Security and the Environment, 345 ScI. 325, (2014); Robert F. Service, New Recipe Produces Ammonia from Air, Water, and Sunlight, 345 ScI. 610, 610 (2014).

145. Rod A. Herman et al., Bringing Policy Relevance and Scientific Discipline to Environmental Risk Assessment for Genetically Modified Crops, 31 TRENDs BIOTECHNOLOGY 493, 495 (2013).

146. Id.

147. Fedoroff, supra note 119; see also, Peter Barfoot \& Graham Brookes, Key Global Environmental Impacts of Genetically Modified (GM) Crop Use 1996-2012, 5 GM Crops \& Food: Biotechnology Agric. \& Food Chain 149, 152-53 (2014). It should be noted that this study received funding from Monsanto. Id. at 159.

148. Id. at 154.

149. GM Eucalyptus Approve in Brazil, 348 Scr. 264, 264 (2015). 
signed these trees, hopes to decrease its carbon footprint by decreasing the distance the wood must travel in order to reach the mills. ${ }^{150}$

One new area of research is that of the environmental benefits of GE crops. Perhaps it is possible to modify crops so that they add to the nitrogen content of soil. We should ask questions about whether biotechnology can be used to alleviate the harms of past farming practices.

Another area to consider, which is circular in nature, is whether we need to invest in new forms of GE crops that can withstand the negative consequences of climate change, such as drought or heat. ${ }^{151}$ That is, farming may contribute to global climate change-and even farming of GE crops may contribute to global climate change-but then we need a food supply that can flourish in the very environment that we created. Since many factors contribute to global warming, with agriculture being only one of them, we will have to identify and create ways not only to combat climate change, but, frankly, to survive it. This is particularly true for the food supply in developing countries. ${ }^{152}$

Another environmental concern is adventitious presence (AP). ${ }^{153}$ AP occurs when a trace amount of an unapproved GE product is found in a commercial crop or food supply. ${ }^{154}$ This could occur during field trials of a test crop. ${ }^{155}$ Low Level Presence (LLP) occurs when an approved GE crop in at least one country is found in a commercial crop or food supply in another country that has not approved that GE crop variety. ${ }^{156}$ Thus, the difference between AP and LLP is the regulatory status. ${ }^{157}$ In either case, seed dispersal, pollination, and other mechanisms leading to AP or LLP are concerns, but these are likely manageable concerns.

Given the natural mechanism of seed dispersal, conventional breeding, which also creates genetically modified products, can also "contaminate" commercial crops and the food supply. But concerns about seed dispersal from conventional breeding do not create the same type of hype because those crops are not created by biotechnology.

The concerns about AP and LLP are nuanced, and a one-size-fitsall policy will not appreciate or address the concerns. Some crops have been highly selected for certain traits over time, but conventional

150. $I d$.

151. Cf. Naglaa A. Abdallah et al., Editorial, The Impact of Possible Climate Changes on Developing Countries, 5 GM Crops \& Food: Biotechnology Agric. \& Food Chain 77, 77-79 (2014).

152. Id.

153. Strauss \& Sax, supra note 13 , at $475-76$.

154. Sarah Lukie, Ask Us Anything About GMOs!: Expert Answer, GMO ANSWERS (Jan. 14, 2014, 5:00 PM), https://gmoanswers.com/ask/what-adventitious-pres ence-and-it-fixed-cpb [https://perma.cc/KB5R-MKJZ]

155. See id.

156. Id.

157. $I d$. 
breeding techniques may only provide "limited success." 158 Genetically engineered trees, for example, face particular issues given that they may face multiyear delays for flowering compared to annual crops. ${ }^{159}$ Field methods and other precautionary approaches can protect against AP and LLP, but technology is needed to address pressing needs to help forests cope with environmental stresses. ${ }^{160}$ Some GE approaches do not introduce a novel gene or trait; rather, it is increasing the expression of an advantageous endogenous allele. ${ }^{161}$ As such, the risk associated with AP and LLP may be different with different types of genetic modifications.

In other scenarios, a novel trait or gene is created through the application of biotechnology. Resistance to particular pests can be imparted by putting a particular gene into a crop. ${ }^{162}$ This is an advantageous trait allowing a particular crop to survive (resist) viral infection, leading to higher yields, which can translate to less water, fertilizer, and energy needed to grow a crop. In these situations, biotechnology is able to achieve something that is nearly impossible to do with conventional breeding. These types of changes require regulatory approval (or de-regulation depending on the regulatory structure), meaning that any AP or LLP is potentially a problem.

Concerns over AP and LLP should focus on safety, environmental risk, and other considerations rather than the technology deployed. The costs associated with an AP or LLP event are enormous due to embargoes, lost crops, etc. ${ }^{163}$ But the costs associated with low-level AP and LLP do not match up to the risks. As previously proposed, workable tolerances should be established. ${ }^{164}$

\section{Herbicide-Resistant Weeds}

The advent of GE crops that are herbicide resistant could mean that farmers will rely heavily on herbicides to kill weeds and not be inclined to use other techniques for weed control, such as rotating crops, tilling, and rotating herbicides. ${ }^{165}$ Via natural selection, weeds will acquire the traits that allow them to resist current herbicides, including glyphosate. That is, repeated and consistent use of herbicides will select for weeds that can withstand them. So in the absence of other farming techniques, herbicide-resistant GE crops may not provide the type of protection over the long term that they promise. And farmers

158. Strauss \& Sax, supra note 13, at 475; Steven H. Strauss, et al., 349 SCIENCE 794, 795 (2015).

159. Strauss, supra note 158 at 794-795 (2015).

160. Id.

161. See generally Luisa Bortesi \& Rainer Fischer, The CRISPR/Cas9 System for

Plant Genome Editing and Beyond, 33 Biotechnology Advances 41 (2015).

162. Saletan, supra note 25 (discussing "The Papaya Triumph").

163. Strauss \& Sax, supra note 13 , at 475.

164. Id. at 476.

165. Editorial, A Growing Problem, 510 Nature 187, 187 (2014). 
will increasingly face problems with herbicide-resistant weeds. Again, scientific studies are needed to address this issue.

Some data exist that transgenes for herbicide resistance appear in wild-type varieties, although no data exist that this causes any negative ecological effects. ${ }^{166}$ Nonetheless, concerns that crossbreeding between GE crops and wild-type plants poses a potential problem. ${ }^{167} \mathrm{~A}$ study by Yorike Hartman and colleagues demonstrates that the location of the transgene in the GE crop impacts the effect of a GE-wildtype cross. ${ }^{168}$ Many crop varieties contain domestication genes that tend to lower the fitness of that crop in a wild environment. ${ }^{169}$ Hartman and colleagues showed that insertion of the transgene in a GE crop near a region that conferred a selective disadvantage, such as delayed flowering, affects the ability of a transgene to actually survive in a wild environment. ${ }^{170}$ This potentially provides important information for the designers of GE crops. For example, the exogenous DNA that leads to herbicide resistance should be inserted into a particular location in the genome that is near an area that confers a selective disadvantage.

Public debate, which is focused on safety and labeling, is missing the real concerns. The concerns should be whether GE technology can be utilized to solve problems. While many in the scientific community understand the real concerns, the public needs to be educated so they can appropriately assign risk. Our regulatory policies ought to recognize the many decades of research on GE food and push for sciencebased solutions to our growing food-supply and environmental issues.

\section{CONCLUSION}

Important health and safety issues exist around our food supply, but these issues do not and should not include whether currently tested GE foods are safe for consumption. The mainstay of the public debate about GE foods, such as whether GE foods are safe for ingestion, is based on non-scientific data. This is reminiscent of the public debate over the safety of vaccines and the connection to autism (of which there is none).

Some of the public debate over the safety of consumption may be clouded by a public dislike of the practices of large agriculture companies. ${ }^{171}$ But these are separate issues and should be treated separately.

166. Yorike Hartman et al., Genomic Regions in Crop-Wild Hybrids of Lettuce Are Affected Differently in Different Environments: Implications for Crop Breeding, 5 EvOlutionary Applications 629, 629 (2012); see also GMO Green Light, 512 NATURE 118, 118 (2014).

167. See Laura Vargas-Parada, GM Maize Splits Mexico, 511 Nature 16, 16 (2014).

168. Hartman et al., supra note 166, at 629-30.

169. Id. at 629 .

170. Id.

171. Ottoline Leyser, Moving Beyond the GM Debate, PLOS BIOLOGY, June 2014, at 1,1 . 
Studies aimed at understanding why consumers assign a high risk to GE foods could provide important information. Specifically, studying whether the role of affect might be contributing to consumer perceptions could provide important insight not only for understanding consumer concerns but also for determining how to assuage these concerns. ${ }^{172}$

Real scientific concerns remain. Can GE foods improve our food supply and farming techniques, allowing food to reach places with malnourishment problems, without harming the environment? This is where the debate should be, and we need scientific studies to address these important issues. ${ }^{173}$ One advantage of GE food is that the modification to the host crop is known at a molecular level. This allows for specific tests to determine toxicity or allergenicity. ${ }^{174}$

The real question should be: Can GE crops produce the types of advantages that they promise? ${ }^{175}$ Scientific studies should evaluate whether GE techniques are likely to produce or whether we should be exploring other avenues to obtain the desired effects.

172. Sax, Biotechnology and Consumer Decision-Making, supra note 1.

173. See Donald Kennedy, Editorial, Building Agricultural Research, 346 Scr. 13, 13 (2014) (calling for increased agriculture research). Cf. 8 Ways Monsanto Fails at Sustainable Agriculture: \#7 Suppressing Research, Union Concerned SCIENTISTs, http:// www.ucsusa.org/food_and_agriculture/our-failing-food-system/genetic-engineering/ suppressing-research.html [https://perma.cc/Q9S3-K365] (last revised Jan. 9, 2012) (suggesting that companies need to make their GM seeds available for scientific studies).

174. Bawa \& Anilakumar, supra note 47, at 1039.

175. See Gurian-Sherman, supra note 117, at 5; $c f$. The Cost of Native and GM Cotton Crops, 522 Nature 130, 130 (2015) (addressing costs of growing conventional versus GE cotton). 
